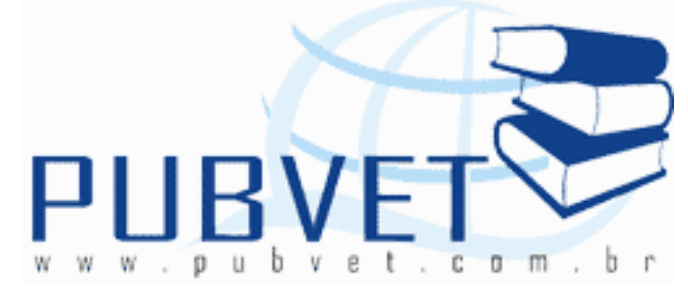

PUBVET, Publicações em Medicina Veterinária e Zootecnia.

\title{
Efeito do nível de células somáticas sobre o rendimento do queijo prato
}

Karyne Oliveira Coelho ${ }^{1}$; Aline Alves da Silva²; Paulo Divino Cesar Braga ${ }^{3}$; Kátia Leda de Oliveira ${ }^{4}$; Camila Silveira Melo ${ }^{5}$; Cláudia Peixoto Bueno ${ }^{5}$

${ }^{1}$ Professora Doutora da Universidade Estadual de Goiás e Serviço Nacional de Aprendizagem Comercial.

${ }^{2}$ Bolsista PIBIC/CNPq e graduanda do Curso de Tecnologia em Laticínios/UEG.

${ }^{3}$ Mestrando em Ciências Contábeis da Fundação Escola de Comércio Álvares Penteado (FECAP) e Professor Esp. da Universidade Federal de Goiás.

${ }^{4}$ Tecnóloga em Laticínios;

${ }^{5}$ Professora Doutora da Universidade Estadual de Goiás.

\section{Resumo}

O presente trabalho foi proposto com o objetivo verificar o efeito dos níveis de células somáticas no leite sobre o rendimento do queijo Prato. Para concretizar tal objetivo, foram selecionados animais com contagem de células somáticas $\geq 100$ mil células/mL; CCS $>100$ a $\geq 400$ mil células $/ \mathrm{mL}$; CCS $>400$ mil células $/ \mathrm{mL}$ e que não tinham recebido tratamento com antimicrobianos nos dias anteriores, considerou-se o período de carência da base utilizada. Com o leite obtido foram produzidos, no período de agosto de 2009 a junho de 2010, os queijos pratos. Foram fabricados cinco lotes de cada grupo. Durante o processamento foi realizado à avaliação de rendimento e rendimento ajustado. 
COELHO, K.O. et al. Efeito do nível de células somáticas sobre o rendimento do queijo prato. PUBVET, Londrina, V. 6, N. 15, Ed. 202, Art. 1352, 2012.

Observou-se no presente estudo que a CCS influenciou negativamente o rendimento do queijo prato.

Palavras-chave: Lucro; Pecuária Leiteira; Qualidade

\title{
Effect of somatic cell count on yield in Prato cheese
}

\begin{abstract}
The present study was proposed to evaluate the effect of levels of somatic cells in the milk on Prato cheese yield. To achieve this goal, we selected animals with somatic cell count $\geq 100.000$ cells $/ \mathrm{mL}$; SSC $\geq 100$ to 400.000 cells $/ \mathrm{mL}$; $\mathrm{SSC}>400.000$ cells $/ \mathrm{mL}$. The animals did not receive antimicrobial treatment before and on the day of the milk collection. Five batches were manufactured from each group. During processing was performed to assess income and adjusted income. Observed in this study that the SSC negatively affected the yield of cheese.
\end{abstract}

Keywords: Dairy Farming; Earnings; Quality

\section{Introdução}

O queijo Prato é classificado como gordo e de média umidade, sendo um dos queijos mais fabricados no Brasil. Foi introduzido na década de 20, na região do sul de Minas Gerais, por imigrantes dinamarqueses, sendo originado dos queijos Dambo dinamarquês e Gouda holandês (Baldini et al., 1998). Possui grande importância no meio comercial, ocupando o segundo lugar em produção no Brasil. Esse tipo de queijo caracteriza-se por ter sabor suave, consistência macia, fácil fatiabilidade e melhor padronização tecnológica, sendo, portanto, mais bem caracterizado comercialmente (ABIQ, 2011).

Considerando a importância econômica deste derivado, faz-se necessário o controle do processo de elaboração. Assim sendo, ressalta-se que a qualidade e a composição do queijo são influenciadas pelas características físico-químicas e microbiológicas do leite e pelo processo de fabricação, incluindo a escolha do coalho e da cultura láctica, bem como das etapas de 
COELHO, K.O. et al. Efeito do nível de células somáticas sobre o rendimento do queijo prato. PUBVET, Londrina, V. 6, N. 15, Ed. 202, Art. 1352, 2012.

tratamento da massa, ponto de corte, agitação e a temperatura de aquecimento. Estes fatores determinam a eficiência da coagulação, o rendimento de fabricação e as características de textura e consistência do produto final (Albuquerque \& Macedo, 2003).

No que concerne, ao rendimento, observa-se que vários fatores podem cursar com alteração deste parâmetro. O rendimento em queijo tem sido objeto de pesquisa acadêmica e industrial há anos e é fator determinante no preço do leite e na eficiência da fabricação. Uma das questões básicas que determinam o rendimento de queijo é o efeito da composição do leite, ou seja, quanto maior o conteúdo total de sólidos do leite, maior será o rendimento, entre os fatores que pode alterar a composição, destaca-se a ocorrência de mastite em rebanhos leiteiros.

Nesse contexto, pode-se indicar a mastite, especialmente, a forma subclínica, como a principal doença dos rebanhos leiteiros, que afeta diretamente a produção e a composição do leite e, conseqüentemente, a manufatura dos derivados (Bueno et al., 2003). A mastite ocasiona um aumento na liberação de células, de diversos tipos no leite, sendo que a gravidade da doença geralmente é proporcional à contagem de células somáticas (CCS) obtida no produto (Coelho, 2004). Considerando a relação direta entre a ocorrência de mastite sub-clínica e a CCS no leite, justifica-se a importância da CCS como parâmetro para avaliar a qualidade do leite não processado (Machado et al., 2000).

O efeito do aumento da CCS no leite sobre o rendimento e a qualidade na fabricação de queijos tem sido estudado. No entanto, a maioria das pesquisas se atém aos queijos tipo Cheddar ou Cottage, não enfocando a realidade brasileira, já que a produção no país é direcionada, principalmente, para os queijos tipo Mussarela, Minas Frescal e Prato. Porém, nas pesquisas realizadas com diferentes derivados lácteos, observa-se que o aumento da CCS no leite causa diminuição do rendimento industrial, perda de qualidade nutricional e diminuição da vida de prateleira do produto (Auldistist \& Hublle, 1998; Santos et al., 2004). 
Considerando os aspectos mencionados, o presente trabalho foi proposto com objetivo de avaliar o efeito dos níveis de células somáticas no leite sobre o rendimento do queijo Prato

\section{Material e Métodos}

O processamento dos queijos foi realizado uma vez ao mês durante cinco meses, no período de setembro de 2009 a junho de 2010, totalizando cinco lotes de cada grupo. O leite foi obtido em uma propriedade leiteira localizada no município de São Luís de Montes Belos, Goiás. A referida propriedade possui 20 animais em lactação, da raça Girolanda. O sistema de ordenha é mecânico com balde ao pé.

Para obtenção do leite foram selecionados vacas, entre aquelas que apresentarem estágio de lactação superior a 10 dias e que não tenham sido submetidos ao tratamento com antimicrobianos, considerando o período de carência da base terapêutica utilizada. Para a seleção dos animais foram colhidas amostras de leite de cada vaca em lactação para a realização das seguintes análises, determinação da contagem de células somáticas (CCS) e composição, gordura, proteína, lactose e sólidos totais.

Foram selecionados cinco animais com níveis de células somáticas baixo ( $\leq 100$ mil céls. $/ \mathrm{mL}$ ), cinco com níveis médios ( $\geq 100$ a $\leq 400$ mil céls. $/ \mathrm{mL}$ ), cinco com níveis alto ( $\geq 400 \mathrm{mil}$ cél $/ \mathrm{mL}$ ). Formando os grupos 1,2 e 3 . As vacas escolhidas foram submetidas à ordenha três dias após a colheita e análise de CCS e composição, para a obtenção do leite (200L), necessário para realização do experimento, sendo que cada grupo foi ordenhado separadamente.

O leite de cada grupo de vacas foi colhido em latões de polipropileno higienizados, com capacidade para 50 litros, em duas ordenhas, manhã e tarde, totalizando 150 litros de cada grupo. Os latões foram acondicionados em câmara fria a $5^{\circ} \mathrm{C}$, para refrigeração e armazenamento, até o momento de sua utilização. 
A determinação da CCS, Contagem Bacteriana Total (CBT), percentual de gordura, proteína, lactose e sólidos totais no leite cru, foram analisados eletronicamente no Laboratório de Qualidade do Leite, EV/UFG.

O queijo Prato foi processado em um Laticínio localizado em São Luís de Montes Belos. Cada tipo de leite, considerando, o Grupo de células somáticas, foi processado separadamente de acordo com as recomendações de Furtado (2005), observando-se as boas práticas de fabricação.

O rendimento de cada queijo foi calculado de duas maneiras: a) o volume em litros de leite necessário para a elaboração de um quilo de queijo (L/kg). Neste caso, dividiu-se o volume de leite utilizado pela soma da massa dos queijos obtidos; b) a massa em gramas de sólidos totais de queijo por litro de leite (g ST/L) (FURTADO; 2005).

O delineamento experimental foi do tipo aleatorizado em blocos. Os resultados foram analisados através de Análise de Variância (ANOVA), utilizando-se o teste de Tukey para verificar diferenças entre as médias.

\section{Resultados e Discussão}

Na Tabela 1 pode-se observar a influência da CCS sobre o rendimento industrial e o rendimento corrigido dos queijos elaborados com leite contendo três níveis de CCS, ou seja, Grupo1: leite com CCS baixa ( $\leq 100.000$ cél/mL); Grupo2: leite com CCS média (>100 000 cél/mL $\leq 400.000$ cél/mL); Grupo3: leite com CCS intermediária (>400 000 cél/mL).

Os valores de rendimento (litros de leite/ $\mathrm{kg}$ de queijo) e rendimento ajustado (litros de leite/kg de extrato seco de queijo) para os diferentes tratamentos diferiram entre si $(p \leq 0,05)$. Observa-se que os queijos elaborados com leite contendo CCS superior a 400 mil céls./mL apresentaram menor rendimento industrial. Tal fato ocorre possivelmente devido ao menor teor de proteína encontrado no leite do Grupo 4. 
COELHO, K.O. et al. Efeito do nível de células somáticas sobre o rendimento do queijo prato. PUBVET, Londrina, V. 6, N. 15, Ed. 202, Art. 1352, 2012.

Tabela 1 - Rendimento do queijo Prato queijos elaborado com leite contendo diferentes níveis contagem de células somáticas, São Luís de Montes Belos, $\mathrm{GO}$.

Parâmetros

avaliados

\section{Contagem de Células Somáticas} Grupo 1

\section{Grupo 2}

$9,6 \pm 1,32^{\mathrm{a}}$

$9,0 \pm 1,18^{\mathrm{a}}$
Grupo 3

$10,9 \pm 1,87^{b}$

Rendimento ajustado ${ }^{2}$

$8,9 \pm 1,19^{a}$

$10,3 \pm 1,72^{b}$

${ }^{1}$ litros de leite/kg de queijo; ${ }^{2}$ litros de leite/kg de extrato seco de queijo; valores com mesma letra na linha não diferiram significativamente entre si $(p \leq$ 0,05); Grupo1: leite com CCS baixa ( $\leq 100.000$ cél $/ \mathrm{mL})$; Grupo2: leite com CCS média (>100 000 cél $/ \mathrm{mL} \leq 400.000$ cél $/ \mathrm{mL}$ ); Grupo3: leite com CCS intermediária ( $>400000$ cél/mL).

A qualidade inicial do leite é a primeira condição para se obter um bom rendimento industrial, observa-se que a CCS, pode comprometer este indicador. Isto ocorre possivelmente porque a ocorrência de mastite cursa com mudanças nas concentrações dos principais componentes do leite, proteína, gordura, lactose e minerais, além do aumento das enzimas proteolíticas, fatores que mudam os aspectos relacionados à elaboração do produto. As alterações nas frações de proteínas do leite causadas pela mastite apresentam importantes implicações sobre o potencial do leite como matéria-prima para a fabricação de derivados, em especial de queijo, pois o rendimento industrial do leite está associado principalmente à fração de caseína (Auldist \& Hublle, 1998; Ma et al., 2000).

Ao considerar a média dos tratamentos avaliados neste experimento quanto à quantidade de leite gasto para produzir $1,0 \mathrm{Kg}$ de queijo prato, salienta-se que com aumento da CCS de 100 para 400 mil céls $/ \mathrm{mL}$, gasta-se, aproximadamente, 1,2 litros de leite a mais. Considerando que o preço pago ao produtor é de cerca de 0,8220 centavos o litro, em cada $1,0 \mathrm{~kg}$ de queijo produzido ter-se-á um prejuízo de 0,9864 centavos. Para uma fábrica que produz $1000 \mathrm{~kg}$ semanais, o prejuízo será $986,4 \mathrm{R} \$$ por semana, $3.945 \mathrm{R} \$$ por 
COELHO, K.O. et al. Efeito do nível de células somáticas sobre o rendimento do queijo prato. PUBVET, Londrina, V. 6, N. 15, Ed. 202, Art. 1352, 2012.

mês e 47.347R\$ por ano, o que justifica a adoção de medidas de controle e monitorização da mastite, visando à diminuição da CCS e com isso à maximização quanto ao rendimento.

\section{Conclusão}

De acordo com as condições de realização do presente experimento, observou-se que a CCS influenciou negativamente o rendimento do queijo Prato.

\section{Referências}

ABIQ - ASSOCIAÇÃO BRASILEIRA DAS INDÚSTRIAS DE QUEIJO. Disponível em: http://www.abiq.com.br. Acesso em 18 de maio de 2011.

ALBUQUeRQUE, L. C., MACEDO, M. A. Os queijos no mundo. Juiz de Fora: ILCT, 2003.

AUDISTIST, M.J.; HUBLLE, I.B. Effects of mastitis on raw milk and dairy products. Australian Journal of Dairy Technology, Melbourne, v.53, p.28-36, 1998.

BALDINI, V. L. S.; CAMPOS, S. D. S.; SILVA, A. T.; VAN DENDER, A. G. F.; LAJOLO, F. M. Alterações das características químicas e de textura do queijo tipo Pratoao longo do processo de maturação. Revista do Instituto de Laticínios Cândido Tostes, Juiz de Fora, v. 53, n. 304, p. 53-59, 1998.

BUENO, V.F.F. Impacto do Grupo de células somáticas sobre a composição do leite. 2004. 70f. Dissertação (Mestrado em Ciência Animal)-Escola de Veterinária, Universidade Federal de Goiás, Goiânia.

COELHO, K.O. Impacto dos eventos ocorridos antes e após o parto sobre o desempenho produtivo e reprodutivo da lactação anterior e da posterior de vacas Holandesas. 2004. $70 f$. Dissertação (Mestrado em Ciência Animal)-Escola Superior de Agricultura "Luiz de Queiroz", Universidade de São Paulo, Piracicaba.

FURTADO, M. M. Principais problemas dos queijos: causas e prevenção, 2. ed. São Paulo: Fonte Comunicações e Editora, 2005. 200 p.

MA, Y., RYAN, C., BARBANO, D. M., GALTON, D. M., RUDAN, M., BOOR, K. Effects of somatic cell count on quality and shelf-life of pasteurized fluid milk. Journal of Dairy Science. v. 83, n. 1, p. 1-11, 2000.

MACHADO, P.F.; PEREIRA, A.R.; SILVA, L.F.P. Células somáticas no leite em rebanhos brasileiros. Scientia Agrícola, São Paulo, v.57, n.2, p.359-361, 2000.

SANTOS, M.V.; MA, Y.; CAPLAN' Z.; BARBANO, D.M. Effect of Somatic Cell Count on Proteolysis and Lipolysis in Pasteurized Fluid Milk During Shelf-Life Storage. Journal of Dairy Science, Champaign, v.90, n.8, p.2491-2503, 2004. 